\title{
Hubungan Pengetahuan Siaga Gempa Bumi dan Sikap Siswa terhadap Kesiapsiagaan di SD Negeri 2 Cepokosawit
}

\author{
Rinta Tyas Puji Lestari', Tri Susilowati², Hermawati ${ }^{3}$ \\ Universitas 'Aisyiyah Surakarta \\ E-mail: rintatyas6@gmail.com, asaku_susi@yahoo.com, \\ hermawatifarid@rocketmail.com \\ Doi: https://doi.org/10.30787/gaster.v18i2.523 \\ Received: February 2019| Revised: January 2020| Accepted: July 2020
}

\begin{abstract}
ABSTRAK
Latar Belakang: Indonesia berada pada wilayah ring of fire (cicin api), salah satu bencana yang sering terjadi adalah gempa bumi, angka kejadian gempa bumi di indonesia mencapai 10 kali lipat tingkat kegempaan. Untuk mengurangi dampak bencana gempa bumi perlu adanya pengetahuan, sikap, dan kesiapsiagaan seluruh masyarakat yang rentan terhadap kesiapsiagaan. Tujuan: Mengetahui hubungan pengetahuan siaga gempa dan sikap siswa terhadap kesiapsiagaan. Metode: Jenis penelitian ini Analitik Cross Sectional. Jumlah sampel 43 siswa, instrumen ini menggunakan kuesioner. Analisa data menggunakan analisa Chi Square. Hasil: Pengetahuan siswa tentang siaga gempa bumi dalam kategori cukup (53,5\%), sikap siswa dalam kategori cukup (51,2\%), kesiapsiagaan siswa dalam kategori hampir siap (34,9\%). Ada hubungan yang signifikan antara pengetahuan siaga gempa bumi terhadap kesiapsiagaan diperoleh nilai (p-value=0,000). Ada hubungan sikap siswa terhadap kesiapsiagaan diperoleh nilai ( $p$-value $=0,000)$ Simpulan: Ada hubungan pengetahuan siaga gempa bumi dan sikap siswa terhadap kesiapsiagaan.
\end{abstract}

Kata Kunci : Gempa Bumi; Kesiapsiagaan; Pengetahuan; Sikap

\section{ABSTRACT}

Background: Indonesia is located on the Ring of Fire region (ring of fire), one of the frequent disasters are earthquakes, the incidence of earthquakes in Indonesia reached 10 times the level of seismicity. To reduce the impact of the earthquake need their knowledge, attitudes, and preparedness throughout the community, including students who are vulnerable to disasters. Objective: To examine the relationship earthquake standby knowledge and students' attitudes towards preparedness. Metode: The study Analytical Cross Sectional. Total sample of 43 students, this instrument using a questionnaire. Data were analyzed using Chi Square analysis. Result: Knowledge of students on standby earthquakes in the category enough (53.5\%), the attitude of the students in the category enough (51.2\%), the preparedness of students in a category is almost ready $(34.9 \%)$. There was a significant correlation between knowledge of earthquakes on preparedness 
standby obtained value ( $p$-value $=0.000)$. There was a significant correlation anatara students' attitudes towards preparedness is obtained by value (p-value $=0.000)$. Conclusion: There is a relationship earthquake standby knowledge and attitudes towards preparedness.

Keywords : Earthquake; Preparedness; Knowledge; Attitude

\section{PENDAHULUAN}

Bencana secara sederhana didefinisikan sebagai suatu gangguan serius terhadap suatu masyarakat sehingga menyebabkan kerugian yang meluas pada kehidupan manusia dari segi materi, ekonomi atau lingkungan dan yang melampaui kemampuan masyarakat tersebut. Bencana dapat disebabkan oleh kejadian alam atau natural disaster maupun faktor ulah manusia atau man-made disaster. Bencana alam seperti banjir, gunung meletus, gempa bumi, tanah longsor, tsunami, serta badai petir. Bencana ulah manusia seperti akibat dari teknologi, terorisme, dan biologis. Bencana alam dari sekian banyak jenisnya, gempa bumi termasuk yang paling dahsyat. Gempa bumi tidak mengenal waktu karena bisa terjadi kapan saja, sepanjang tahun, dengan dampak buruk terjadi secara mendadak dan hanya memberikan sedikit isyarat bahaya (Dien, et al, 2015)

Gempa Bumi 12 Mei 2008 di Sichuan, China, memberikan gambaran besarnya dampak ketika bencana terjadi pada saat jam sekolah. Gempa berkekuatan 7,9 skala
Richter itu menewaskan 87.000 orang dengan sedikitnya 5.335 murid. Artinya sekitar 6\% korban tewas adalah anak-anak sekolah. Berdasarkan laporan media pemerintah China, lebih dari 7000 bangunan sekolah runtuh dan menimbun para pelajar dan guru. Berdasarkan data yang didapat oleh peneliti setiap tahun diperkirakan sekitar 66 juta anak diseluruh dunia terkena dampak bencana (Dien, et al, 2015).

Secara Geografis Indonesia merupakan negara kepulauan yang terletak pada pertemuan empat lempeng yaitu Benua Asia, Benua Australia, Samudra Hindia dan Samudra Pasifik. Pada bagian selatan dan timur Indonesia terdapat sabuk vulkanik yang memanjang dari Pulau Sumatera, Jawa, Nusa Tenggara, Sulawesi yang berupa pegunungan vulkanik tua dan dataran rendah yang sebagian didominasi oleh rawa-rawa. Kondisi tersebut sangat berpotensi sekaligus rawan bencana seperti letusan gunung berapi, gempa bumi, tsunami, banjir, dan tanah longsor. Data menunjukkan bahwa Indonesia merupakan salah satu negara yang memiliki tingkat kegempaan yang tinggi didunia, lebih dari 
10 kali lipat tingkat kegempaan di Amerika Serikat (Rinanda, 2013).

Gempa Bumi pada tanggal 27 Mei 2006 adalah gempa bumi berkekuatan 5,9 skala Richter, yang berlangsung selama 57 detik pada pukul 05:55 WIB mengguncang Yogyakarta dan sebagian Jawa Tengah. Desa Cepokosawit, Kecamatan Sawit, Kabupaten Boyolali membangun monumen gempa bumi yang akan menjadi pengingat bagi warga Cepokosawit bahwa pernah terjadi bencana alam besar 12 tahuan silam, yakni gempa bumi Yogyakarta dan Jawa Tengah. Gempa tersebut menyebabkan 4 warga Boyolali meninggal dunia, 300 warga mengalami luka-luka, 715 rumah warga hancur dan 825 rumah rusak. Meskipun dampaknya tidak separah di Kabupaten Bantul dan sekitarnya, dan gempa bumi juga menyisakan luka bagi warga yang ada di daerah tersebut (Anafiah \& Arief, 2018).

Kesiapsiagaan sangatlah penting untuk warga boyolali khususnya daerah cepokosawit mengingat bahwa jumlah korban jiwa dan kehilangan materi yang tidak sedikit disetiap kejadian bencana. Gempa Bumi tersebut membuat banyak orang terperangkap didalam rumah khususnya anak-anak dan orangtua kareana terjadi pada pagi hari sehingga mayoritas korban merupakan orang berusia lanjut dan anak-anak yang kemungkinan tidak sempat menyelamatkan diri ketika gempa berlangsung, hal ini memperlihatkan masih lemahnya kesiapsiagaan menghadapi bencana (Indiasari, 2016).

Beberapa faktor yang menjadi penyebab utama timbulnya banyak korban dan kerugian saat gempa bumi adalah kurangnya pengetahuan masyarakat dan anak-anak tentang bencana, bahaya, sikap, atau perilaku yang mengakibatkan penurunan sumberdaya alam, dan kurangnya kesiapan masyarakat dalam mengantisipasi bencana tersebut. Selain dipengaruhi oleh faktor diatas, gempa bumi juga dipengaruhi oleh tingkat resiko bencana dan selain ditentukan oleh potensi bencana juga ditentukan oleh upaya mitigasi dan kesiapan dalam mengahadapi bencana, kemampuan dan sumberdaya yang terbatas untuk mengontrol atau mempersiapkan diri ketika merasa takut sehingga sangat bergantung pada pihak-pihak diluar dirinya supaya dapat pulih dan kembali dari bencana (Firmansyah, et al, 2014).

Anak-anak merupakan salah satu kelompok rentan yang paling beresiko terkena dampak bencana. Kerentanan anakanak terhadap bencana dipicu oleh faktor pemahaman tentang risiko disekeliling mereka, yang berakibat tidak adanya 
kesiapsiagaan dalam menghadapi bencana. Berdasarkan data kejadian bencana dibeberapa daerah banyak korban terjadi pada anak usia sekolah. Hal ini menunjukkan bahwa pentingnya pengetahuan pendidikan siaga bencana dapat dilakukan sejak dini melalui program siaga bencana disekolah sejak dini supaya anak-anak dapat mengetahui bagaimana cara menyelamatkan diri saat terjadi bencana.

Pendidikan siaga bencana dapat diawali pada anak usia sekolah dasar karena pada masa ini merupakan fase operasional konkrit. Salah satu pendidikan pada siswa adalah mengedukasikan kesehatan dimana peran perawat juga sebagai edukator. Kegiatan pendidikan yang dilakukan dengan memberikan informasi dengan cara menyebarkan pesan, menanamkan keyakinan sehingga bisa mengerti dan juga mampu melaksanakan suatu anjuran yang ada hubungannya dengan kesehatan (Indiasari, 2016).

Berdasarkan studi pendahuluan yang telah dilakukan di SD N 2 Cepokosawit pada bulan November 2018, Kepala Sekolah menyampaikan bahwa di SD N 2 Cepokosawit sudah pernah belajar tentang kesiapsiagaan bencana di Monumen Gempa Bumi 2006 Cepokosawit, tetapi hanya pada siswa kelas
6 saja, sedangkan kelas 1 sampai kelas 5 belum pernah belajar tentang kesiapsiagaan bencana gempa bumi. Kepala Sekolah juga menyampaikan siswa hanya belajar mengenai sejarah berdirinya monumen, gambaran desa Cepokosawit waktu gempa, penyebab terjadinya gempa, belajar mengenai simulasi saat terjadi gempa dan benda-benda bersejarah yang ada di monumen, dan pada saat pembelajaran kesiapsiagaan di monumen hanya menggunakan ceramah saja.

\section{BAHAN DAN METODE}

Metode penelitian menggunakan analitik dengan pendekatan Cross Sectional. Populasi pada penelitian ini adalah 73 siswa. Pengambilan sampel menggunakan total sampling sebanyak 43 siswa yang mempunyai kriteria inklusi yaitu siswa yang bersedia menjadi responden, siswa yang belum pernah mendapatkan sosialisasi kesiapsiagaan gempa bumi, sedangkan kriteria eksklusinya yaitu siswa yang sedang sakit, siswa yang tidak masuk sekolah dan siswa yang mengalami gangguan mental. Penelitian ini menggunakan instrumen kuesioner pengetahuan siaga gempa bumi, sikap, dan kesiapsiagaan. Analisa data menggunakan analisa Chi Square. 


\section{HASIL DAN PEMBAHASAN}

1. Pengetahuan siaga gempa bumi

Tabel 1. Gambaran Pengetahuan siaga gempa bumi di SD $\mathrm{N} 2$ Cepokosawit Bulan Mei Tahun 2019

Pengetahuan Frekuensi (n) Persentase

$(\%)$

\begin{tabular}{ccc}
\hline Cukup & 23 & 53,5 \\
Baik & 20 & 46,5 \\
Total & 43 & 100 \\
\hline
\end{tabular}

Berdasarkan tabel 4.1 dapat diketahui bahwa responden tertinggi memiliki pengetahuan dalam kategori cukup yaitu sebanyak 23 siswa $(53,5 \%)$, dan responden terendah memiliki pengetahuan dalam kategori baik sebanyak 20 siswa $(46,5 \%)$.

Hasil penelitian menunjukkan bahwa responden terbanyak memiliki pengetahuan yang cukup. Pengetahuan adalah hasil tahu dan ini terjadi setelah orang mengadakan penginderaan terhadap suatu objek tertentu. Pada penginderaan sampai menghasilkan pengetahuan tersebut sangat dipengaruhi oleh intensitas perhatian persepsi terhadap obyek. Sebagian besar pengetahuan manusia diperoleh melalui mata dan telinga. (Notoatmodjo,
2003) dalam (Wawan \& Dewi, 2010). Lingkungan merupakan kondisi yang ada disekitar manusia dan pengaruhnya yang dapat mempengaruhi perkembangan dan perilaku orang atau kelompok. Sedangkan sosial budaya adalah sistem yang ada pada masyarakat dapat mempengaruhi dalam menerima informasi (Wawan \& Dewi, 2010). Dalam penelitian ini siswa mendapatkan pengetahuan tentang kesiapsiagaan dengan memperhatikan obyek serta pengalaman yang berada lingkungan sekitarnya yaitu lingkungan tempat tinggalnya yang merupakan daerah rawan gempa dan belum pernah mendapatkan informasi tentang kesiapsiagaan gempa.

Pendidikan sangat diperlukan untuk mendapatkan informasi misalnya halhal yang menunjang kesehatan sehingga meningkatkan kualitas hidupnya, pendidikan dapat mempengaruhi seseorang termasuk juga perilaku seseorang terhadap pola hidupnya (Nursalam (2003) dalam Wawan \& Dewi, 2010). Dalam penelitian ini, guru sekolah adalah orang yang berpendidikan yang membantu dalam mentransfer pengetahuan tentang kesiapsiagaan kepada siswa. 
Usia adalah umur individu yang terhitung mulai saat dilahirkan sampai ulang tahun. semakin cukup umur, tingkat kematangan dan kekuatan seseorang akan lebih matang dalam berfikir (Wawan \& Dewi, 2010). Dalam penelitian ini responden belum berada pada tingkat kematangan untuk menyerap informasi karena masih berada di sekolah dasar. Umur siswa dalam penelitian ini rata-rata 8-10 tahun, pada usia 8-10 tahun memasuki tahap piaget atau tahap operasional konkret dimana pola pikir masih samar-samar dan tidak jelas, sehingga pengetahuan mereka masih dalam kategori cukup, semakin bertambah umur maka pengetahuan siaga bencana akan meningkat.

2. Sikap siswa tentang siaga gempa bumi

Tabel 2. Gambaran Sikap Siswa di SD N 2 Cepokosawit Bulan Mei Tahun 2019

\begin{tabular}{ccc}
\hline Sikap & Frekuensi (n) & $\begin{array}{c}\text { Persentase } \\
(\%)\end{array}$ \\
\hline Cukup & 22 & 51,2 \\
Baik & 21 & 48,8 \\
Total & 43 & 100 \\
\hline
\end{tabular}

Berdasarkan tabel 4.2 dapat diketahui bahwa responden tertinggi memiliki sikap dalam kategori cukup sebanyak 22 siswa
(51,2\%). Responden terendah memiliki sikap dalam kategori baik sebanyak 21 siswa $(48,8 \%)$.

Hasil penelitian ini sikap responden dalam kategori cukup dalam siap siaga gempa bumi. Teori mengemukakan bahwa sikap adalah predisposisi untuk melakukan atau tidak melakukan suatu perilaku tertentu, sehingga sikap bukan hanya kondisi internal psikologis yang murni dari individu, tetapi sikap lebih merupakan proses kesadaran yang sifatnya individual. Faktor-faktor yang mempengaruhi sikap adalah pengalaman pribadi, pengaruh orang lain yang dianggap penting, pengaruh kebudayaan, media massa, lembaga pendidikan dan lembaga agama, dan faktor emosional (Thomas \& Znaniecki (1920) dalam Wawan \& Dewi, 2010). Sikap cukup siaga gempa bumi siswa didapatkan dari cerita yang diwariskan dari pengalamanpengalaman orangtua dan guru yang pernah mengalami bencana gempa bumi.

Priyanto (2006) dalam Rosyida \& Khofifatu (2017) menyatakan bahwa pengalaman menunjukkan bahwa kesiapan menghadapi bencana seringkali terabaikan pada masyarakat. Pengalaman pribadi dapat menjadi dasar pembentuk 
sikap, pengalaman pribadi haruslah meninggalkan kesan yang kuat. Sikap akan lebih mudah terbentuk apabila pengalaman pribadi tersebut terjadi dalam situasi yang melibatkan faktor emosional. Responden belum pernah mempunyai pengalaman pribadi kejadian gempa bumi sehingga belum membentuk sikap kewaspadaan terhadap bencana yang kemungkinan akan dihadapi.

Faktor lembaga pendidikan dan lembaga agama juga mempengaruhi sikap, konsep moral dan ajaran dari lembaga pendidikan dan lembaga agama sangat menentukan sistem kepercayaan (Wawan \& Dewi, 2010). Peneliti juga berpendapat bahwa kurangnya materi kebencanaan di lembaga pendidikan mengakibatkan sikap siaga gempa bumi siswa berada dalam kategori cukup.

3. Kesiapsiagan siswa

Tabel 3. Gambaran Kesiapsiagaan di SD N 2 Cepokosawit Bulan Mei Tahun 2019

\begin{tabular}{ccc}
\hline Kesiapsiagaan & $\begin{array}{c}\text { Frekuensi } \\
\text { (n) }\end{array}$ & $\begin{array}{c}\text { Persentase } \\
\text { (\%) }\end{array}$ \\
\hline Hampir siap & 15 & 34,9 \\
Siap & 14 & 32,6 \\
Sangat Siap & 14 & 32,6 \\
Total & 43 & 100 \\
\hline
\end{tabular}

Berdasarkan tabel 4.3 dapat diketahui bahwa responden tertinggi memiliki kesiapsiagaan dalam kategori hampir siap yaitu sebanyak 15 siswa (34,9\%).

Berdasarkan hasil penelitian tentang kesiapsiagaan siswa di SD $\mathrm{N}$ Cepokosawit, kesiapsiagaan siswa dalam kategori hampir siap. Teori mengemukakan kesiapsiagaan adalah serangkaian kegiatan yang dilakukan untuk mengantisipasi bencana melalui pengorganisasian serta melalui langkah yang tepat guna dan berdaya guna (UU no. 24 tahun 2007).

Firmansyah et al menyampaikan bahwa perencanaan kedaruratan adalah seluruh kegiatan yang meliputi aspek perencanaan dan penanganann kedaruratan, pada saat menjelang, saat darurat dan sesudah keadaan darurat. Perencanaan darurat yang baik dapat memberikan dampak yang positif pada perilaku kesiapsiagaan. Kemampuan dalam melakukan pertolongan pertama dan pengetahuan kebencanaan sangat penting dalam perencanaan kedaruratan. Mayoritas responden dalam kategori kesiapsiagaan hampir siap, ini sesuai pernyataan dari guru SD N 2 Cepokosawit bahwa siswasiswi kelas 3-5 belum pernah belajar 
tentang kesiapsiagaan gempa bumi, sehingga mereka tidak tahu bagaimana cara siap siaga gempa bumi.

Hal ini sejalan oleh penelitian Rusiyah (2014) bahwa pembelajaran materi kebencanaan di tingkat sekolah dasar pada umumnya masih kurang, oleh karena itu, lembaga pendidikan formal maupun non formal memiliki peran yang strategis dalam upaya peningkatan kesadaran pentingnya kesiapsiagaan anak-anak terhadap bencana. Materi kebencanaan dapat dijadikan materi tambahan yaitu membahas bagaimana mensikapi kejadian bencana alam

Pengetahuan merupakan faktor utama dan menjadi kunci kesiap-siagaan. Pengetahuan yang dimiliki biasanya dapat mempengaruhi sikap dan kepedulian untuk siaga dalam mengantisipasi bencana. Faktor utama yang dapat mengakibatkan bencana tersebut menimbulkan korban dan kerugian besar yaitu kurangnya pemahaman tentang karakteristik bahaya, sikap atau perilaku yang mengakibatkan penurunan sumber daya alam, kurangnya informasi peringatan dini yang mengakibatkan ketidaksiapan dan tidak berdayaan atau ketidakmampuan dalam menghadapi bencana (LIPI-UNESCO, 2006).
Bencana gempa bumi dapat terjadi kapan saja dan dapat menimpa siapapun, sehingga kesiapsiagaan siswa dalam menghadapi bencana mutlak diperlukan. Guru atau pembimbing agama merupakan sumber pengetahuan dan mempunyai tanggung jawab yang besar dalam penyelamatan siswa, apabila bencana terjadi pada saat jam belajar. Guru juga berkewajiban meningkatkan pengetahuan tentang kebencanaan. Peningkatan kesiapsiagaan guru dan siswa pada lembaga pendidikan merupakan upaya mewujudkan program pengurangan resiko bencana berbasis masyarakat. Menurut peneliti kesiapsiagaan siswa masih dalam kategori hampir siap dikarenakan oleh faktor pengetahuan siswa. Pengetahuan siswa disini masih dalam kategori cukup sehingga kesiapsiagaan siswa juga masih dalam kategori hampir siap. Selain pengetahuan sikap juga mempengaruhi kesiapsiagaan siswa, disini sikap siswa juga masih dalam kategori cukup sehingga kesiapsiagaan siswa masih dalam kategori hampir siap.

Penelitian ini sejalan dengan penelitian Damayanti (2015) dalam Murbawanetal(2017)menjelaskanbahwa salah satu faktor yang menyebabkan tingkat rencana tanggap darurat dalam 
menghadapi bencana tergolong sedang adalah karena banyaknya responden yang tidak mengetahui jalur evakuasi. Penelitian ini, peran sekolah dan pemerintah masih kurang terutama untuk rencana tanggap darurat yang masih perlu ditingkatkan seperti belum adanya jalur evakuasi yang ditetapkan oleh pemerintah, berbagai latihan terkait rencana tanggap darurat dan berbagai sosialisasi. Terkait dengan jalur evakuasi, dapat diketahui bahwa sebagian siswa belum mengetahui arti penting penetapan jalur evakuasi pada saat bencana gempa bumi terjadi. Ketiadaan jalur evakuasi yang jelas mempengaruhi kesiapsiagaan siswa.

4. Hubungan pengetahuan siaga gempa bumi terhadap kesiapsiagaan di SD Negeri 2 Cepokosawit

Tabel 4. Hasil Analisis pengetahuan siaga gempa bumi terhadap kesiapsiagaan di SD N 2 Cepokosawit Bulan Mei Tahun 2019

\begin{tabular}{cccccccc}
\hline & \multicolumn{6}{c}{ Kesiapsiagaan } & \\
\cline { 2 - 6 } Pengetahuan & $\begin{array}{c}\text { Hampir } \\
\text { Siap }\end{array}$ & \multicolumn{2}{c}{ Siap } & Sangat Siap & \multirow{2}{*}{$\mathrm{P}$} \\
\cline { 2 - 6 } & $\mathrm{N}$ & $\%$ & $\mathrm{~N}$ & $\%$ & $\mathrm{~N}$ & $\%$ & \\
\hline Cukup & 15 & 34,9 & 8 & 18,6 & 0 & 0 & $<0,001$ \\
Baik & 0 & 0 & 6 & 14 & 14 & 32,6 & \\
Total & 15 & 34,9 & 14 & 32,6 & 14 & 32,6 & \\
\hline
\end{tabular}

Berdasarkan tabel 4.4 dapat diketahui bahwa mayoritas responden mempunyai pengetahuan cukup dan kesiapsiagan hampir siap yaitu sebanyak 15 siswa (34,9\%). Hasil analisa selanjutnya dengan uji chi square diperoleh p-value $<0,001$ yang artinya ada hubungan pengetahuan siaga gempa bumi terhadap kesiapsiagaan di SD N 2 Cepokosawit.
Hal ini sesuai dengan teori Rogers dalam Wawan dan Dewi (2010) yang menyatakan bahwa pengetahuan kognitif merupakan domain yang sangat penting bagi terbentuknya perilaku, dan perilaku yang didasari pengetahuan akan bertahan langgeng dari pada perilaku yang tidak didasari pengetahuan. Oleh sebab itu pemberian stimulus yang positif berupa 
pemberian informasi-informasi melalui media penyuluhan, pelatihan secara berkesinambungan ternyata mampu memberikan dampak yang positif dalam peningkatan pengetahuan siaga gempa bumi.

\section{Penelitian LIPI-UNESCO/ISDR} (2006) tentang kesiapsiagaan masyarakat pedesaan Aceh menghadapi bencana, menunjukkan bahwa pengetahuan mempunyai pengaruh terhadap tingkat kesiapsiagaan menghadapi bencana pada masyarakat pedesaan Aceh. Selanjutnya menjelaskan bahwa pengetahuan merupakan faktor utama kunci kesiapsiagaan. Upaya meningkatkan pengetahuan melalui pendidikan kebencanaan diharapkan dapat meningkatkan perilaku kesiapsiagaan seseorang.

Hasil penelitian sebelumnya oleh Rusiyah (2017) pada siswa taman pendidikan Al-Qur'an Al-Khair Kabupaten Bonebalango menunjukkan bahwa terdapat hubungan antara pengetahuan dengan kesiapsiagaan. Hal ini disebabkan sebagian besar dari siswa di Taman Pendidikan Al-Qur'an sudah pernah mengikuti ceramah atau sosialisasi tentang pendidikan mitigasi bencana yang diselenggarakan oleh perguruan tinggi dalam kegiatan pengabdian masyarakat.
Penelitian lain menurut Sugara et al (2018) tentang hubungan pengetahuan dengan sikap kesiapsiagaan masyarakat menghadapi erupsi gunung kelud pada fase mitigasi menyatakan bahwa ada hubungan yang signifikan antara pengetahuan dan sikap kesiapsiagaan masyarakat. Hal ini disebabkan pengetahuan baik terhadap erupsi gunung kelud mampu meningkatkan kesiapsiagaan. Pengetahuan yang baik akan menimbulkan keinginan masyarakat untuk selalu siap dalam menghadapi adanya bencana yang terjadi.

Penelitian yang lain dari Firmansyah et al (2014) di SMA Al-Hasan Kemiri menyatakan bahwa ada hubungan yang signifikan antara pengetahuan dan perilaku kesiapsiagaan dalam mengahadapi bencana banjir. Hal ini disebabkan responden penelitian ini adalah penduduk asli yang telah merasakan bencana banjir daan longsor, sehingga pada umumnya siswa sudah memiliki pengalaman mengenai bencana tersebut sehingga dapat mempengaruhi perilaku kesiapsiagaan.

Pengetahuan dan kesiapsiagaan memiliki arah hubungan yang positif, artinya semakin tinggi pengetahuan maka perilaku kesiapsiagaannya juga akan 
meningkat. Sebagian besar responden mempunyai pengetahuan yang cukup maka perilaku kesiapsiagaan juga dalam kategori hampir siap.

5. Hubungan sikap siswa terhadap kesiapsiagaan di SD Negeri 2 Cepokosawit

Tabel 5. Hasil Analisis sikap siswa terhadap kesiapsiagaan di SD N 2 Cepokosawit Bulan Mei Tahun 2019

\begin{tabular}{cccccccc}
\hline & \multicolumn{5}{c}{ Kesiapsiagaan } & \multirow{2}{*}{ P } \\
\cline { 2 - 6 } Sikap & Hampir Siap & \multicolumn{2}{c}{ Siap } & \multicolumn{3}{c}{ Sangat Siap } & \\
\cline { 2 - 6 } & $\mathrm{N}$ & $\%$ & $\mathrm{~N}$ & $\%$ & $\mathrm{~N}$ & $\%$ & \\
\hline Cukup & 14 & 32,6 & 8 & 18,6 & 0 & 0 & $<0,001$ \\
Baik & 1 & 2,3 & 6 & 14 & 14 & 32,6 & \\
Total & 15 & 34,9 & 14 & 32,6 & 14 & 32,6 & \\
\hline
\end{tabular}

Berdasarkan tabel 4.5 dapat diketahui bahwa responden terbanyak ada 2 kelompok dengan nilai yang sama, kelompok pertama memiliki sikap cukup dan kesiapsiagaan dalam kategori hampir siap yaitu 14 siswa $(32,6 \%)$, sedangkan kelompok kedua memiliki sikap baik dan kesiapsiagaan dalam kategori sangat siap yaitu 14 siswa (32,6\%). Responden terkecil memiliki sikap baik dan berada dalam kategori kesiapsiagaan siap yaitu sebanyak 6 siswa (14,0\%). Hasil analisa selanjutnya dengan uji chi square diperoleh $\mathrm{p}$-value $<0,001$ yang artinya bahwa ada hubungan sikap siswa terhadap kesiapsiagaan di SD N 2 Cepokosawit.

Hal ini sesuai teori sikap adalah predisposisi untuk melakukan atau tidak melakukan suatu perilaku tertentu, sehingga sikap bukan hanya kondisi internal psikologis yang murni dari individu, tetapi sikap lebih merupakan proses kesadaran yang sifatnya individual (Thomas \& Znaniecki, 1920) dalam Wawan dan Dewi (2010). Menurut pendapat peneliti sikap yang peduli menjadikan semangat untuk tindakan kesiapsiagaan untuk diri sendiri maupun orang lain sehingga proses penyelamatan diri saat bencana dapat terjadi. Sikap dapat mempengaruhi kesiapsiagaan seseorang, sikap siaga yang baik maka kesiapsiagaan juga akan semakin baik. Sikap dalam menghadapi bencana gempa bumi merupakan faktor penentu kesiapsiagaan karena sikap berhubungan 
dengan persepsi kepribadian dan motivasi. Sikap juga mempengaruhi kesiapsiagaan, karena sikap merupakan bagian dari proses manajemen bencana. Sikap responden penelitian ini adalah cukup sehingga kesiapsiagaan responden berada dalam kategori hampir siap.

Hasil penelitian Lenawida (2011) dalam Bukhari et al(2014) menunjukkan bahwa pengetahuan, sikap, dan dukungan anggota keluarga berpengaruh secara signifikan tergadap kesiapsiagaan rumah tangga dalam menghadapi bencana. Sikap merupakan faktor yang paling domain mempengaruhi kesiapsiagaan dalam menghadapi bencana, sikap siap siaga yang baik terhadap kejadian bencana maka kesiapsiagaan juga akan sangat baik. Hasil penelitian ini sesuai dengan penelitian Bukhari et al (2014) bahwa ada hubungan yang signifikan antara sikap tentang regulasi terhadap kesiapsiagaan bencana gempa bumi di layanan umum daerah rumah sakit ibu dan anak pemerintah Aceh. Hal ini disebabkan sikap yang baik dalam kesiapsiagaan mempunyai peluang 8.750 kali untuk kesiapsiagaan yang baik dalam menghadapi bencana.

\section{SIMPULAN DAN SARAN}

Simpulan dari penelitian ini yaitu mayoritas pengetahuan dan sikap siswa tentang siaga gempa bumi dalam kategori cukup, sebagian besar kesiapsiagaan siswa berada di kategori hampir siap, ada hubungan pengetahuan siaga gempa terhadap kesiapsiagaan siswa dan ada hubungan sikap siswa terhadap kesiapsiagaan di SD N 2 Cepokosawit.

Materi kebencanaan bisa dijadikan materi tambahan yang membahas bagaimana mensikapi kejadian bencana alam dari aspek agama dan membahas surat-surat dan ayat ayat Al-Qur'an yang berkaitan dengan bencana alam dikaitkan dengan pentingnya sikap siaga gempa bumi. Sekolah dapat melakukan simulasi kesiapsiagaan bencana gempa bumi sehingga siswa akan lebih siap dalam menghadapi bencana.

\section{DAFTAR PUSTAKA}

Anafiah, S., dan Ardian, A. (2018). Pembuatan Buku Cerita Anak Bermuatan Penanggulangan Bencana di SD Bangunrejo 1, SDN Bangunrejo 2, dan SDB Baluwarti Yogyakarta. Jurnal ABDI Volume 2 Nomor 2. 
Bukhari, Mudatsir, \& Sri, A. S. (2014). Hubungan Tentang Regulasi, Pengetahuan Perawat Terhadap Kesiapsiagaan Bencana Gempa Bumi di Badan Layanan Umum Daerah Rumah Sakit Ibu dan Anak Pemerintah Aceh . Jurnal Ilmu Kebencanaan, Volume 21 Nomor 2.

Dien, R. J., Lucky T, K., \& Reginus T, M. (2015). Pengaruh Penyuluhan Kesehatan Terhadap Kesiapsiagaan Menghadapi Bencana Gempa Bumi Pada Siswa SMP Kristen Kakaskasen Kota Tomohon . Jurnal Keperawatan Volume 3 Nomor 2.

Firmansyah, I., Hanny, R., \& Rondhianto. (2014). Hubungan Pengetahuan dengan Perilaku Kesiapsiagaan dalam Menghadapi Bencana Banjir dan Longsor pada Remaja Usia 15-18 tahun di SMA Al-Hasan Kemiri Kecamatan Panti Kabupaten Jember. Artikel Ilmiah Hasil Penelitian Mahasiswa

Indiasari, N. F. (2016). Pengaruh Metode Simulasi Siaga Bencana Gempa Bumi Terhadap Kesiapsiagaan Anak di Yogyakarta. Jurnal Keperawatan Volume 11 Nomor 3.

LIPI-UNESCO/ISDR. (2006). Kajian Kesiapsiagaan Masyarakat dalam Mengantisipasi Bencana Gempa Bumi \& Tsunami. Jakarta: Deputi Ilmu Pengetahuan Kebumian Lembaga Ilmu Pengetahuan Indonesia.

Murbawan, I., Amar, M., \& Abdul, M. (2017). Kesiapsiagaan Rumah Tangga Dalam Mengantisipasi Bencana di Daerah Aliran Sungai (DAS) Wanggu (Studi Bencana Banjir di Kelurahan Lepo-Lepo Kota Kendari). Jurnal Ecogreen

Rinanda, S. (2013). Pengaruh Metode Simulasi Tanggap Bencana Alam Terhadap, Volume 3 Nomor 2. Kemampuan Mitigasi Pada Anak Tunagrahita Ringan di Kelas C/D VI SLB Perwari Padang. Jurnal Ilmiah Pendidikan Khusus Volume 1 Nomor 1

Rosyida, F., \& Khofifatu, R. A. (2017). Studi Eksplorasi Pengetahuan dan Sikap Terhadap Kesiapsiagaan Bencana Banjir di SD Pilanggede Kecamatan Balen Kabupaten Bojonegoro. Jurnal Teori dan Praktis Pembelajaran IPS, Volume 2 Nomor 1

Rusiyah, (2017). Hubungan Pengetahuan dengan Kesiapsiagaan Bencana Gempa Bumi Pada Siswa Taman Pendidikan Al-Qur'an Al-Khair Kabupaten Bonebolango. Jurnal Swarnabhumi Volume 2 Nomor 1. 
Sugara, S. A., Farida, D. K., \& Ani, S. (2018). Hubungan Pengetahuan Sikap Kesiapsiagaan Masyarakat Menghadapi Erupsi Gunung Kelud Pada Fase Mitigasi. Jurnal Nursing Ners, Volume 3 Nomor 1.

UU RI No 24 Tahun 2007. Tentang Penanggulangan Bencana.

Wawan, A\& Dewi, M. 2010. Teori \& Pengukuran Sikap dan Perilaku manusia. Yogyakarta: Nuha Medika. 